\title{
Isolation and identification of a pathogenic bacterium, Exiguobacterium oxidotolerans XP-2, from the abnormal diseased mature sporophytes of a commercially cultivated brown seaweed Saccharina japonica
}

\author{
Rafiq Ahmad ${ }^{1} \cdot$ Yao Chen ${ }^{1} \cdot$ Yingrui Zhuang ${ }^{1} \cdot$ Qiying Qiü ${ }^{2}$. Defu Chen ${ }^{2} \cdot$ Mahasweta Saha ${ }^{3} \cdot$ Hongyan Wu $^{4}$. \\ Gaoge Wang ${ }^{1}$ ()
}

Received: 26 February 2021 / Revised and accepted: 11 May 2021

(C) The Author(s), under exclusive licence to Springer Nature B.V. 2021

\begin{abstract}
Diseases of the commercially cultivated brown seaweed Saccharina japonica have been noticed since the 1960s in China. However, the usually opportunistic nature of the pathogenic bacteria of seaweeds is still a main obstacle for isolating and identifying pathogenic bacteria responsible for causing diseases of the cultivated $S$. japonica. In this study, a Gram-positive bacterium XP-2 was isolated from the abnormal diseased mature sporophytes of $S$. japonica. Pathogenicity test indicated that XP-2 could cause green-rotten disease in healthy juvenile sporophytes and significant algal ultrastructural changes were observed after $S$. japonica was infected by XP-2. The cells shrank, and the thylakoids of the chloroplasts became blurred after $12 \mathrm{~h}$ of re-infection. At $24 \mathrm{~h}$ slight deformation was observed in the structure of the mitochondria, chloroplasts, and nucleus. There also were many vacuoles in the infected cells. After $31 \mathrm{~h}$ of re-infection, mitochondrial structure and thylakoids became more indistinct. SEM and TEM observations indicated that XP-2 was rod-shaped with no flagella. Analysis of the full length 16S rRNA gene sequence and physiological and chemical characteristics indicated that XP-2 was closely related to Exiguobacterium oxidotolerans $12280^{\mathrm{T}}$. Based on these results, XP-2 was designated Exiguobacterium oxidotolerans XP-2. The pathogenicity of $E$. oxidotolerans XP-2 was identified by Koch's Postulate under laboratory conditions. These results enrich the growing list of pathogenic bacteria in commercially cultivated seaweeds and also provide a foundation for investigating the virulence mechanisms of pathogenic bacteria of commercially cultivated seaweeds in the near future.
\end{abstract}

Keywords Abnormal disease $\cdot$ Exiguobacterium oxidotolerans XP-2 - Green-rotten disease $\cdot$ Pathogenic bacteria . Saccharina japonica

\section{Introduction}

Gaoge Wang

gaogewang@hotmail.com

Hongyan Wu

sdwuhongyan@126.com

1 College of Marine Life Sciences and Institute of Evolution \& Marine Biodiversity, Ocean University of China, 266003 Qingdao, China

2 Fujian Lianjiang Guanwu Seafood Developing Product Co., Ltd., Guanwu 350511, China

3 Marine Ecology and Biodiversity, Plymouth Marine Laboratory, Prospect Place, Plymouth PL1 3DH, UK

4 Ludong University, Yantai 264025, China
Epibacterial species associated with seaweeds are diverse and may have beneficial or detrimental effects on their hosts. For example, certain epiphytic bacteria are beneficial for the morphology, growth, and development of many seaweed species (Egan et al. 2013; Singh 2013; Singh and Reddy 2014). However, in some cases, epibacteria associated with macroalgae can become pathogenic and harmful to their hosts and can cause disease outbreaks. Pathogenic bacteria for seaweeds are considered opportunistic pathogenic bacteria, because they are present on the surface of macroalgae and can become pathogenic when environmental conditions change, like increased temperature and the variation of light intensity (Egan et al. 2013; Wang et al. 2014). By using the 
traditional culture-dependent method and re-infection assay, many pathogenic bacteria have been isolated and identified in farmed seaweeds.

Several pathogenic bacterial strains have been reported for various diseases in the farmed seaweeds such as Laminaria/Saccharina, Porphyra/Pyropia and Gracilaria species in China, Japan, and Korea (Gachon et al. 2010; reviewed in Egan et al. 2014). Some of these pathogenic bacteria were identified by fulfilling Koch's postulates (reviewed in Egan et al. 2014). For example, Alteromonas sp., isolated from decaying Laminaria japonica (now Saccharina japonica) (Sawabe et al. 1992), was capable of inducing thallus bleaching lesion on Laminaria religiosa (Vairappan et al. 2001). Pseudoalteromonas elyakovii was considered to be associated with spot-wounded fronds of S. japonica (Sawabe et al. 2000). However, the virulence mechanism of pathogenic bacteria in farmed macroalgae is poorly understood. Firstly, it is difficult to identify the true pathogens from saprophytes or other secondary colonizers that benefit from the diseased macroalgae (Egan et al. 2013). Another reason is that the pathogenic bacteria lose their pathogenicity after being cultured for several generations in laboratory conditions. Thus, there is no stable experimental model for investigating the virulence mechanisms behind the diseases of the farmed macroalgae.

Saccharina japonica is a very important economic seaweed worldwide because of its high consumption as food and utilization in commercial products (FAO 2016). China contributes $60 \%$ of production and $90 \%$ alginate totally (FAO 2016). Since the successful cultivation of S. japonica in 1958, disease outbreaks have been observed at nursery and field cultivation stages (Tseng 1994). However, research work on isolating and identifying the pathogenic bacteria have been conducted only since 1979 (Chen et al. 1979). A large number of epiphytic alginic acid-decomposing bacteria from the diseased $S$. japonica have been isolated and screened in vitro for their ability to induce a disease similar to that observed in the field (e.g., Liu et al. 2002; Wang et al. 2003a). The alginic acid-decomposing bacteria were not the taxonomic terminology for pathogenic bacteria but were referred to all of those bacteria which could decompose the cell wall of the cultivated $S$. japonica (Chen et al. 1979; Wang et al. 2014). The pathogenic alginic aciddecomposing bacteria responsible for the most destructive green rot/falling off disease at nursery stage were identified by Koch's postulates (Chen et al. 1979, 1981; Wang et al. 2003b). Further, it was found that the number of alginic acid-decomposing bacteria on diseased juvenile sporophytes $\left(4.88 \times 10^{7} \mathrm{cfu}^{-1}\right)$ was up to $100-500$ times that of the healthy ones $\left[(0.8-4.3) \times 10^{5} \mathrm{cfu} \mathrm{g}^{-1}\right]$ (Lin et al. 2004). Other than alginic acid-decomposing bacteria, other bacterial genera were also reported to be pathogenic for the cultivated S. japonica. Bacteria of the genus Pseudomonas are known to secrete alginase that can decay the cell wall and cause rotten disease (Chen et al. 1986; Ding 1990) and have been considered to be the major bacterial pathogen for the rotten-diseased juveniles of cultivated $S$. japonica. Alteromonas macleodii is a pathogenic bacterium found to cause rotten disease in healthy $S$. japonica under laboratory conditions (Wang et al. 2004; 2005). Alteromonas espejiana, isolated from bleaching diseased sporophytes of $S$. japonica, was identified as pathogenic bacteria (Wang et al. 2006). Pseudoalteromonas, Vibrio, Halomonas, and Bacillus were dominant bacteria in hole-rotten-diseased sporophytes (Wang et al. 2008). However, whether these dominant bacterial species are pathogenic or not has not been confirmed by re-infection assay. Some pathogenic bacteria have been isolated and identified in cultivated $S$. japonica. However, these pathogenic bacteria are opportunistic, and due to the lack of an experimental model between the pathogenic bacteria and cultivated $S$. japonica, it is difficult to examine the virulence mechanisms.

Recently, disease outbreaks have become very complex in the field cultivation. Diseases may differ from year to year, and it is difficult to track the causative factors for such unidentified diseases. The bottleneck issue is to obtain the pathogenic bacteria that can maintain their pathogenicity in culture, which will help to establish a stable experimental model for studying the virulence mechanisms. The present study aimed to isolate pathogenic bacteria from the abnormal diseased mature sporophytes of commercially cultivated S. japonica. Pathogenicity of the isolated strain was identified by re-infection assay, and finally the strain was identified to the species level. The results of this study will help to establish a stable experimental model between the pathogenic bacterial strain and commercially cultivated $S$. japonica. Detailed knowledge of virulence mechanisms can significantly prevent and mitigate the disease outbreaks during both nursery and field cultivation stages.

\section{Material and methods}

\section{Sample collection}

The abnormal diseased mature sporophytes of $S$. japonica (Fig. 1) were collected on 9 July 2018 from the S. japonica cultivating farms, located in Xiapu, China (N 26 $30^{\prime} 06.87^{\prime \prime}$ E $\left.119^{\circ} 53^{\prime} 34.11^{\prime \prime}\right)$. There were many abnormal diseased areas scattered on the edge of the mature sporophytes with white rotten holes and filamentous epiphytes, penetrating into the epidermal cells (see details in Fig. 1). Three replicate of samples from diseased mature sporophytes were cut into $10 \mathrm{~cm}^{2}$ pieces with a sterile surgical blade and tweezers and were transferred to the laboratory in sterile zip lock plastic bags with ice packs within $20 \mathrm{~h}$ of collection. 
Fig. 1 Abnormal diseased mature sporophytes of cultivated $S$. japonica. A Abnormal diseased mature sporophytes (white arrows showed the disease areas). B The inset indicates the disease symptoms, including white dots (white arrows) and white filamentous epiphytes (white arrows) on the surface of the diseased mature sporophytes. C Healthy mature sporophyte. Bars: A $5 \mathrm{~cm}$; B and $\mathbf{C} 0.5 \mathrm{~cm}$

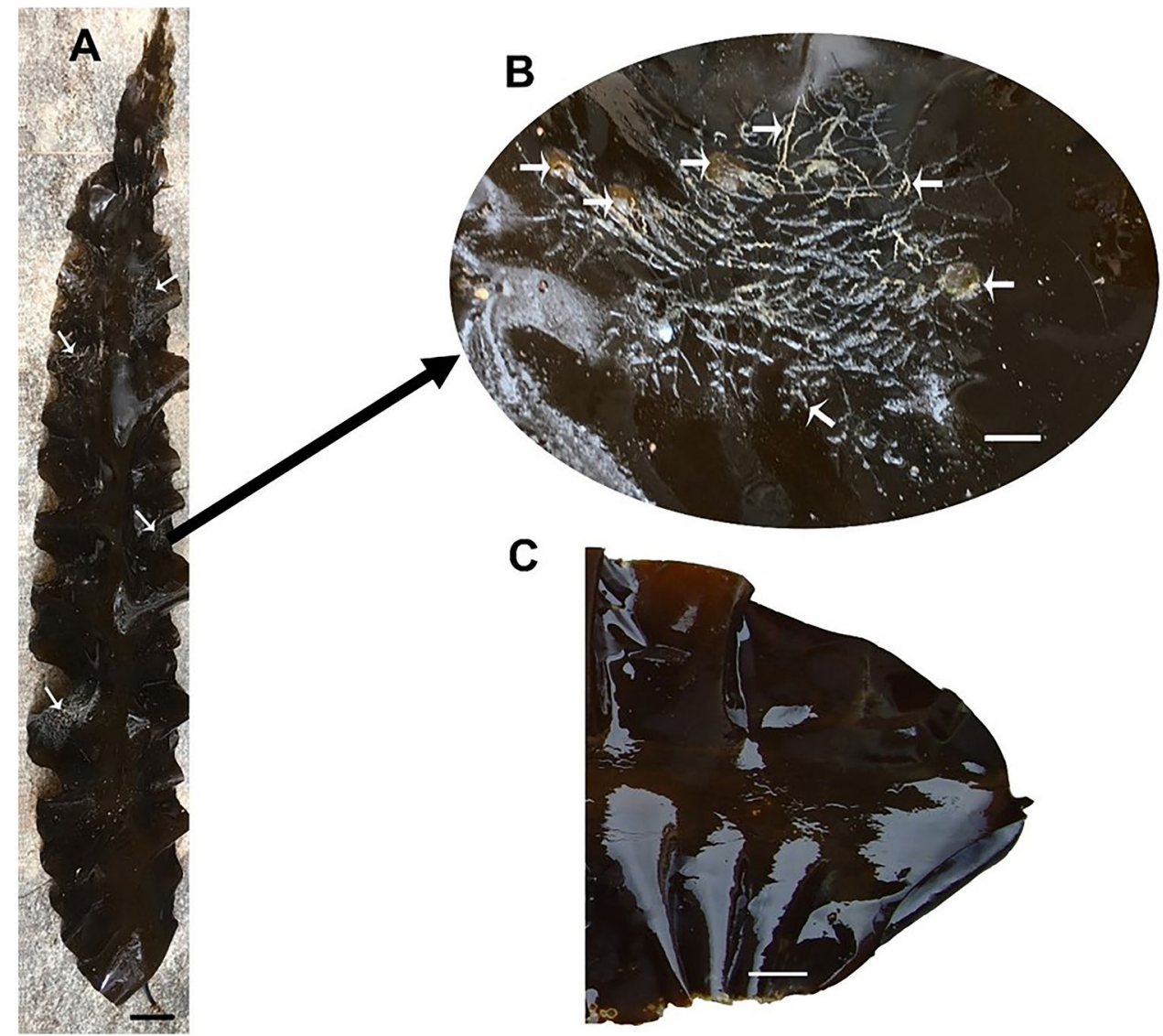

\section{Bacterial isolation}

The diseased tissues of $10 \mathrm{~cm}^{2}$ area were rinsed at least three times with sterile seawater (the salinity of the seawater was about $30 \%$ o) to remove loosely attached free living organisms and other particles. The epiphytic bacteria were isolated from the tissues by using sterile cotton applicator and then were suspended in $5 \mathrm{~mL}$ sterile sea water. The suspension of epiphytic bacteria was diluted using tenfold dilution plate method and spread over Zobell 2216 E marine agar (Ying et al. 2019). A $100 \mu \mathrm{L}$ of each dilution was spread in triplicate on Zobell $2216 \mathrm{E}$ marine agar (Oppenheimer and Zobell 1952). The plates were then incubated at $25{ }^{\circ} \mathrm{C}$ for $24 \mathrm{~h}$. The bacteria were selected on the basis of morphology, such as shape and pigment. The purified strains were obtained by streaking on the plates for three times. The purified bacterial isolates were then stored using $15 \%(\mathrm{v} / \mathrm{v})$ glycerol at $-80{ }^{\circ} \mathrm{C}$ for further analysis.

\section{Re-infection assay}

Pathogenicity tests were carried out according to Wang et al. (2004) to determine whether the isolated strains may cause any disease in healthy $S$. japonica. Fresh healthy juvenile sporophytes $(10 \mathrm{~cm}$ in length) of $S$. japonica were collected from Weihai Changqing Ocean Science \& Technology Co., Ltd, located in Rongcheng, Shandong province, China, on 24 December 2018. After collection samples were processed within $4 \mathrm{~h}$, healthy juvenile sporophytes were cut into small pieces $(1.0 \times 1.0 \mathrm{~cm})$ with a sterile surgical blade. Each tissue was cut in the center and put into 24-well Coster cell culture plates (USA). The tissue sections were treated individually with the isolated strains (density was $1.0 \times 10^{7} \mathrm{cfu} \mathrm{mL}^{-1}$ ). The same size of tissue sections of the healthy juvenile sporophytes were used as a control group and treated with autoclaved Zobell 2216E liquid medium. The plates were then incubated at $10{ }^{\circ} \mathrm{C}$ with $90 \mu \mathrm{mol}$ photons $\mathrm{m}^{2} \mathrm{~s}^{-1}$ (light: dark $=12: 12 \mathrm{~h}$ ) for $35 \mathrm{~h}$. The infected tissues were observed under a light microscope (Nikon, Japan). Replication level was 6. Pathogenicity of the isolated bacterial strains was identified by re-infection assay.

\section{Observations of ultrastructure of the infected S. japonica}

The re-infection assay and the incubation conditions were the same as mentioned in the "Re-infection assay" section. Control and infected tissues were collected at 12, 24, and $31 \mathrm{~h}$ after infection by pathogenic bacteria. Samples were fixed with $2.5 \%$ glutaraldehyde in phosphate buffer for $4 \mathrm{~h}$ 
and then rinsed three times with $0.1 \mathrm{M}$ phosphate buffer saline (PBS) for 15 min and post-fixed with $1 \%$ osmium tetroxide for $1.5 \mathrm{~h}$. Following that, the samples were rinsed with PBS and dehydrated with ethanol $(50 \%, 70 \%, 90 \%$, and $100 \%$ ) for 15 min and kept at room temperature (Maurin et al. 1993). Following Kim et al. (2016), the samples were immersed in Spurr's epoxy resin and polymerized overnight at $72{ }^{\circ} \mathrm{C}$ okdkdven. The samples (thin sections) were stained with uranyl acetate and lead citrate for $15 \mathrm{~min}$. Finally, samples were observed using a JEM-1200EX TEM microscope (JEOL, Japan).

\section{Morphological observations of the pathogenic bacterial strain by scanning electron and transmission electron microscope}

The cell morphology was examined by scanning electron microscope (SEM). The pathogenic bacterial strain was grown on Zobell 2216E Marine broth at $25^{\circ} \mathrm{C}$ for $24 \mathrm{~h}$. The cells were fixed with $2.5 \%(\mathrm{v} / \mathrm{v})$ glutaraldehyde for $4 \mathrm{~h}$ and then rinsed with $0.1 \mathrm{M}$ phosphate buffer. Then the cells were post-fixed in $1 \% \mathrm{OsO}_{4}$ for $2 \mathrm{~h}$, washed with $0.1 \mathrm{M}$ phosphate buffer, and were dehydrated with a graded series of ethanol/ water (10\% v/v to $100 \%)$ at 10 -min intervals. The specimens were passed through 50\% (once) and 100\% isoamyl acetate twice. All samples were critical-point dried and gold-coated. The cells were observed under SEM by using JEM 1200-EX (JEOL, Japan).

The specimens of pathogenic bacteria for transmission electron microscopy (TEM) were referred to Yumoto et al. (2002). Pathogenic bacterial strain was grown on Zobell 2216E Marine broth and incubated at $25^{\circ} \mathrm{C}$ for $24 \mathrm{~h}$. The bacterial cells were suspended in physiological saline solution. A tiny drop of the suspension was mounted on a carbon coated copper grid, following which cells were negatively stained with $1 \%$ phosphotungstic acid. The specimens were observed under with JEM 1200EX TEM microscope (JEOL, Japan).

\section{Molecular identification of the pathogenic bacterial strain}

Molecular identification of pathogenic strain was achieved by blasting the full length of 16S rRNA gene sequence according to Fisher et al. (1998). Bacterial DNA was extracted by using plant DNA kit (Tiangen, China) following protocols of the manufacturer. The full length $16 \mathrm{~S}$ rRNA gene sequence was amplified by PCR, using universal primers (27F: AGAGTTTGATCCTGGCTCAG; 1429R: GGTTACCTTGTTACGACTT) (Moreno et al. 2002). PCR amplification reaction was performed in triplicate of $20 \mu \mathrm{L}$ mixture, containing $11 \mu \mathrm{L}$ of double distilled water, 2.5 $\mu \mathrm{L}$ of $10 \times$ KOD Buffer, $2.5 \mu \mathrm{L}$ of template DNA, $2.5 \mu \mathrm{L}$ of $2.5 \mathrm{mM}$ dNTPs, $1 \mu \mathrm{L}$ of each primer $(5 \mu \mathrm{M})$, and 0.5 $\mu \mathrm{L}$ of KOD polymerase. Amplified DNA fragments were sequenced by Sangon Co., Ltd, Shanghai, China.

Full length 16S rRNA gene sequence of the pathogenic bacterial strain was compared with those other related bacterial species using NCBI data base (https://blast.ncbi.nlm. nih.gov). The 16S rRNA gene sequences of the related bacterial strain were retrieved from the NCBI database (www. ncbi.nlm.nih.gov) and aligned by using the Clustal X 1.81 program (Thompson et al. 1997). Phylogenetic trees were reconstructed based on the neighbor-joining (NJ) (Tamura and Nei 1993). Phylogenetic analysis was carried out by using MEGA X software (Felsenstein 1985; Kumar et al. 2018).

\section{Physiological and chemical characterization by Biolog Gen III Microplate}

Biolog microbial identification system (Biolog, Hayward, USA) was used to classify the physiological fingerprint of the pathogenic bacterial strain according to the manufacturer's protocol. The pathogenic bacterial strain was cultured in Zobell $2216 \mathrm{E}$ marine agar at $25^{\circ} \mathrm{C}$ for $24 \mathrm{~h}$, and bacterial colonies were re-suspended in inoculating fluid A (Biolog). The inoculum was prepared according to the user guidelines, and transmittance of bacterial cell suspension was measured by turbidity meter (Biolog TM).

The $100 \mu \mathrm{L}$ of culture bacteria were inoculated into each well of Gen III microtest device and incubated at $25{ }^{\circ} \mathrm{C}$ for $24 \mathrm{~h}$. The results of the Biolog were obtained at $600 \mathrm{~nm}$ automatically by the standardized Micro station system (Biolog Inc., USA). The results were analyzed on the basis of an extensive species library in the Biolog GEN III database.

\section{Results}

\section{Isolation of bacterial strains from the abnormal diseased mature sporophytes of commercially cultivated S. japonica}

The abnormal disease occurred in mature sporophytes in June 2018 during the nursery stage. The diseased areas (white arrows in Fig. 1A) scattered over the edge of the diseased sporophytes (Fig. 1A). The diseased symptoms included white spots, and more white filamentous epiphytes penetrated into the epidermal cells of the diseased mature sporophytes. (Fig. 1B). Using the conventional culturedependent method, a total of 12 epiphytic bacterial strains were isolated from the abnormal diseased mature sporophytes. The pathogenicity of these strains was determined by re-infection assay. 


\section{Re-infection assay}

The purified isolated bacterial strains $\left(1.0 \times 10^{7} \mathrm{cfu} \mathrm{mL}^{-1}\right)$ were infected to the healthy juvenile sporophytes of $S$. japonica. Among the 12 isolated strains, only XP- 2 could cause green-rotten disease, not abnormal disease. Compared to the control groups (Fig. 2A), no disease symptoms were observed at $12 \mathrm{~h}$ after XP-2 infection (Fig. 2B). The color of the infected tissue became white at $24 \mathrm{~h}$ (Fig. 2C), while at $30 \mathrm{~h}$, the infected tissue turned green (Fig. 2D), and the green infected tissue became rotten at $31 \mathrm{~h}$ (black arrows, Fig. 2E).

Moreover, TEM observations of the infected cells indicated ultrastructure changes after infection by XP-2. In the control groups at 12, 24, and $31 \mathrm{~h}$ (Fig. 3A, B, and $\mathrm{C}$, respectively), the structure of chloroplasts, mitochondria, and nuclei showed the normal morphology during the re-infection assay. After infection by XP- 2 at $12 \mathrm{~h}$, shrinkage of nucleus occurred. Chloroplast thylakoids became less distinct (Fig. 3D). At $24 \mathrm{~h}$ after infection by XP-2, the chloroplast thylakoids deformed, and some vacuoles were observed in the cytoplasm. More shrinkage of nucleus was observed (Fig. 3E). The structure of chloroplasts, mitochondria, and nucleus became indistinct at $31 \mathrm{~h}$ after infection by XP-2 (Fig. 3F).

\section{Morphological characteristics of pathogenic bacterial strain of XP-2}

XP-2 was Gram-positive and appeared as light orange color, forming 1-1.5-mm diameter circular colony with an entire edge (Fig. 4A). SEM (Fig. 4B) and TEM (Fig. 4C) showed that XP-2 strain was rod-shaped, $1.45-2.1 \mu \mathrm{m}$ in length, and $0.7-0.9 \mu \mathrm{m}$ in width with no flagella.

\section{Molecular identification and phylogenetic analysis and verification of Koch's postulates}

The 16S rRNA gene sequence of XP-2 consisted of $1445 \mathrm{bp}$. After blasting the 16S rRNA sequence in NCBI database, it showed $98.95 \%$ similarity with Exiguobacterium oxidotolerans JCM12280 ${ }^{\mathrm{T}}$. The phylogenetic analysis was performed on the basis of $16 \mathrm{~S}$ rRNA gene sequences of other related species (Fig. 5). In the phylogenetic tree, XP-2 clearly clustered with Exiguobacterium oxidotolerans JCM12280 ${ }^{\mathrm{T}}$, and therefore we designated XP-2 as Exiguobacterium oxidotolerans XP-2. The 16S rRNA gene sequence of XP-2 has been deposited in NCBI database with the accession number of MW131367.
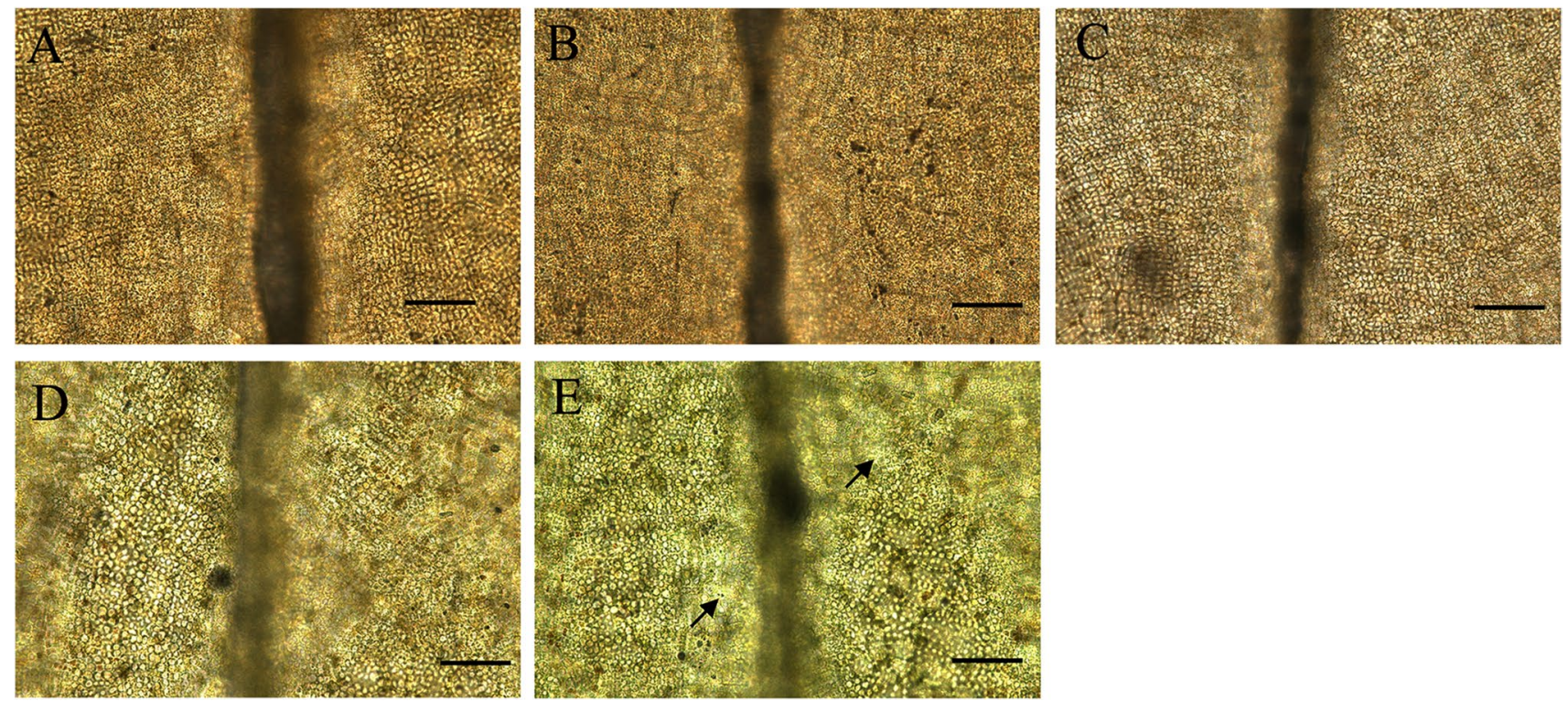

Fig. 2 Re-infected tissues of healthy juvenile sporophytes by XP-2. A control group; B: re-infected tissue of healthy juvenile sporophytes at $12 \mathrm{~h} ; \mathbf{C}$ infected tissue of healthy juvenile sporophytes at $24 \mathrm{~h} ; \mathbf{D}$ green-rotten disease symptoms were observed in the infected tissue at
$30 \mathrm{~h}$; E serious green-rotten disease symptoms (black arrows) examined in the infected tissue of healthy juvenile sporophytes at $31 \mathrm{~h}$. $\mathrm{Bar}=100 \mu \mathrm{m}$ 


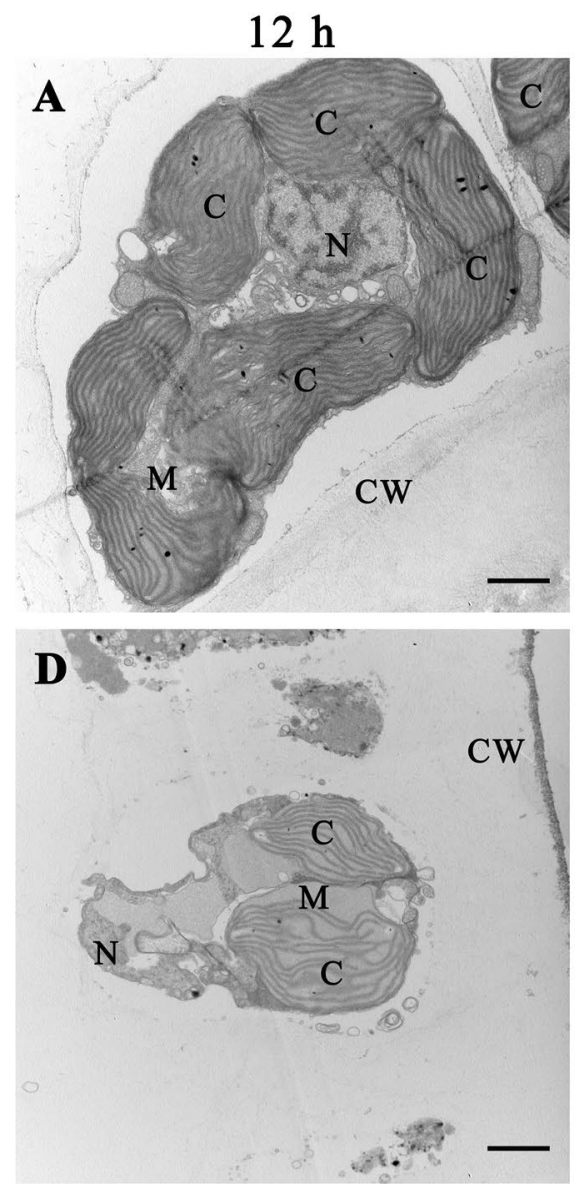

$12 \mathrm{~h}$
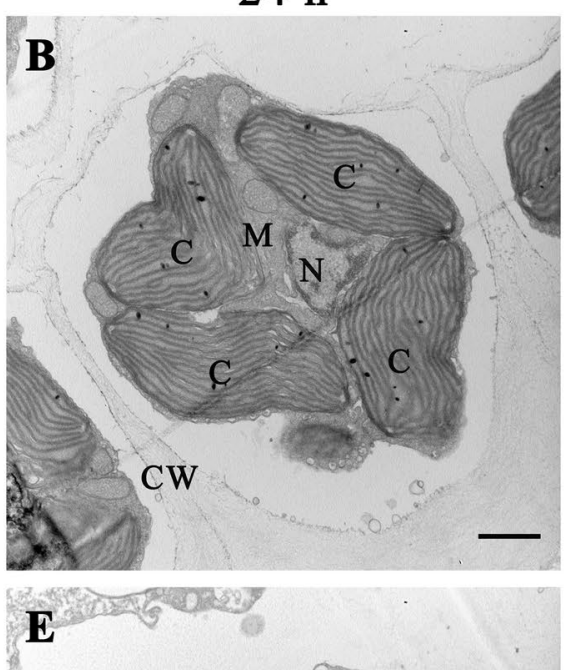

Fig. 3 Ultrastructural changes of the infected $S$. japonica cells by XP-2. A Control group at $12 \mathrm{~h} ; \mathbf{B}$ control group at $24 \mathrm{~h}$; $\mathbf{C}$ control group at $31 \mathrm{~h} ; \mathbf{D}$ re -infected cell at $12 \mathrm{~h} ; \mathbf{E}$ re-infected cell at $24 \mathrm{~h} ; \mathbf{F}$

The bacterial strain re-isolated from green-rotten-diseased tissues of the healthy juvenile sporophytes induced by strain of XP-2 was proven to be the same according to
$31 \mathrm{~h}$
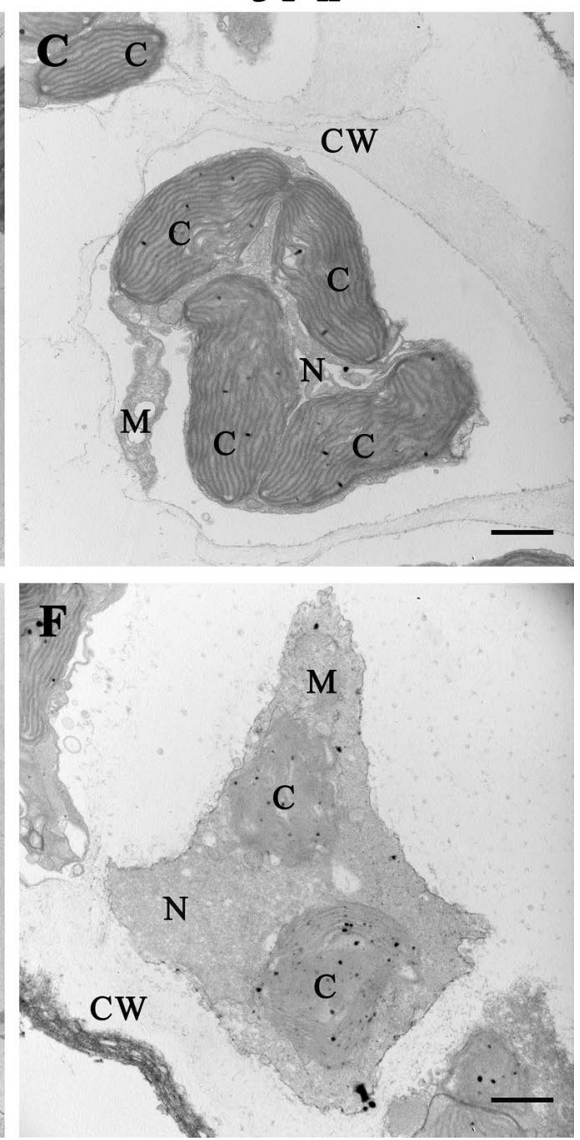
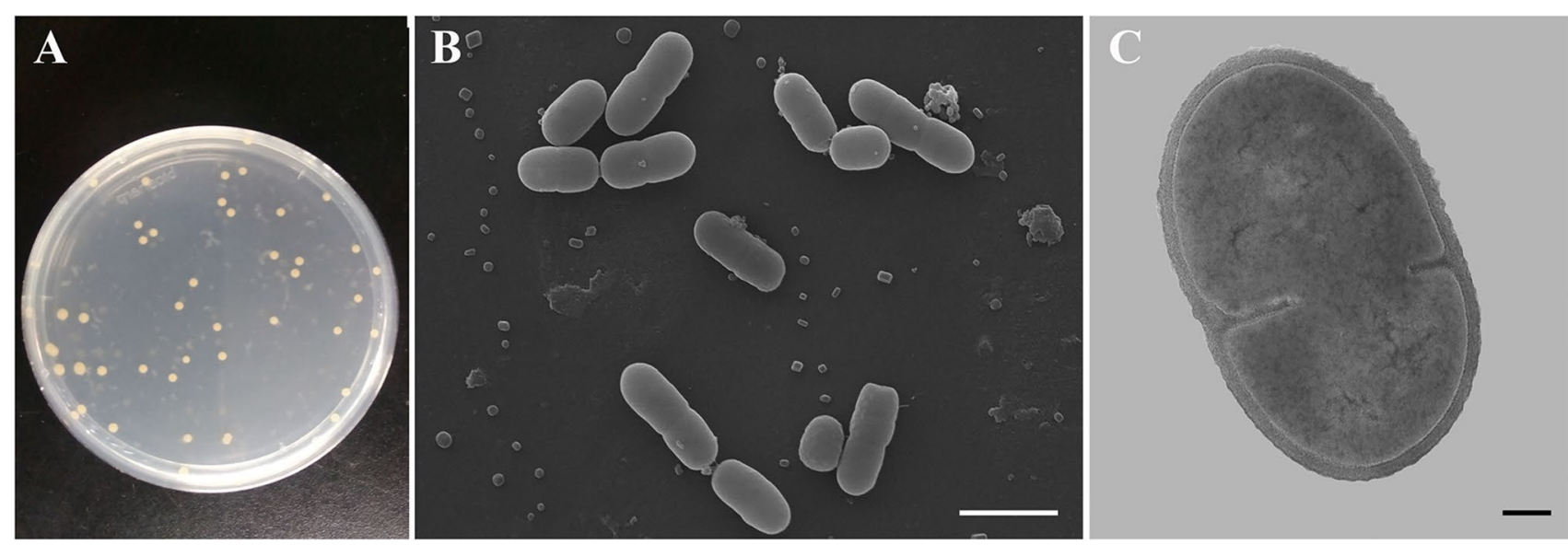

Fig. 4 Morphological characteristics of XP-2. A XP-2 colonies on Zobell 2216E culture medium; B morphology of XP-2 observed by SEM $($ bar $=2 \mu \mathrm{m}) ; \mathbf{C}$ morphology of XP-2 observed by TEM $($ bar $=500 \mathrm{~nm})$ 


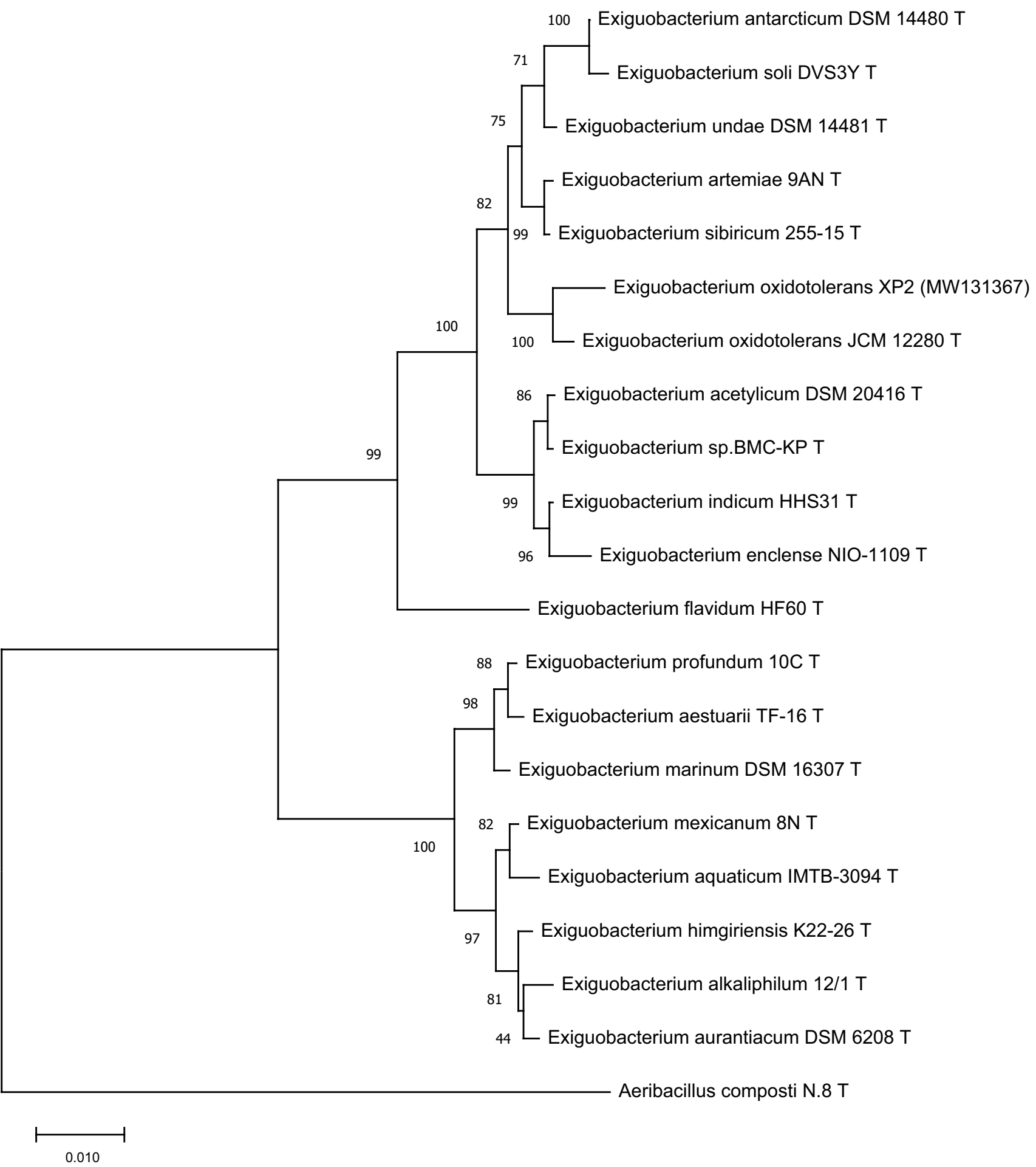

Fig. 5 Phylogenetic tree based on 16S rRNA gene sequences showing the position of XP-2 with other related species using neighbor-joining method. Aeribacillus composti was used as out group. Bootstrap values were shown for the nodes in percentage after 1000 re-samplings. Bar= 0.01 .

\section{Biochemical and physiological characterization of XP-2}

The Biolog Gen III Microplate findings showed that XP-2 utilized carbohydrates, as well as amino acids and other chemical derivatives. The isolated strain XP-2 metabolized a number of carbohydrates, like $\mathrm{D}$-fructose, $\alpha \mathrm{D}$-glucose, D-cellobiose, sucrose, D-trehalose, gentiobiose, propionic acid, pectin, dextrin, hexose $\mathrm{PO}_{4}$ i.e. (D-glucose-6- $\mathrm{PO}_{4}$, D-fructose-6- $\mathrm{PO}_{4}$ ). The metabolized amino acids included 
Table 1 Biochemical and physiological characterization of the XP-2 strain based on Biolog Gen III Microplate

\begin{tabular}{|c|c|}
\hline \multicolumn{2}{|l|}{ Positive reactions } \\
\hline Lithium chloride & Aceto acetic acid \\
\hline D-cellobiose & PH 6 \\
\hline Dextrin & $4 \% \mathrm{NaCl}$ \\
\hline D-gluconic acid & $1 \% \mathrm{NaCl}$ \\
\hline D-fructose & $8 \% \mathrm{NaCl}$ \\
\hline D-mannitol & L-serine \\
\hline Acetic acid & Gentiobiose \\
\hline D-glucose-6- $\mathrm{PO}_{4}$ & Propionic acid \\
\hline D-fructose-6- $\mathrm{PO}_{4}$ & Guanidine $\mathrm{HCl}$ \\
\hline Glycerol & Tween 40 \\
\hline $\mathrm{N}$-acetyl D-glucosamine & Sodium butyrate \\
\hline$\alpha \mathrm{D}$-glucose & ${ }^{\beta}$ Methyl D-glucoside \\
\hline L-alanine & Gelatin \\
\hline Sucrose & L-glutamic acid \\
\hline Inosine & Potassium tellurite \\
\hline \multicolumn{2}{|l|}{ Pectin } \\
\hline \multicolumn{2}{|l|}{ D-trehalose } \\
\hline \multicolumn{2}{|l|}{ Weak positive reactions } \\
\hline D-maltose & D-turanose \\
\hline D-galactose & ramino-butyric acid \\
\hline Mucic acid & $1 \%$ Sodium lactate \\
\hline $\mathrm{N}$-acetyl $\beta \mathrm{D}$-manosamine & L-aspartic acid \\
\hline \multicolumn{2}{|l|}{${ }^{\beta}$ Hydroxy-D,L-butyric acid } \\
\hline \multicolumn{2}{|l|}{ Negative reactions } \\
\hline L-lactic acid & L-malic acid \\
\hline D-lactic acid methyl ester & ${ }^{\alpha}$ Keto-butyric acid \\
\hline L-arginine & D-galacturonic acid \\
\hline D-glucuronic acid & Citric acid \\
\hline D-saccharic acid & L-histidine \\
\hline L-pyroglutamic acid & D-sorbitol \\
\hline 3-Methyl glucose & D-melibiose \\
\hline p-Hydroxy phenylacetic acid & D-malic acid \\
\hline Glycyl-L-proline & Myo-inositol \\
\hline L-galactonic acid lactone & Sodium bromate \\
\hline Quinic acid & D-aspartic acid \\
\hline aketo-Glutaric acid & D-fucose \\
\hline D-serine & D-serine \\
\hline Glucoronamide & $\mathrm{N}$-acetyl D-glactosamine \\
\hline Methyl pyruvate & Tetrazolium Blue \\
\hline L-fucose & Fusidic acid \\
\hline Tetrazolium violet & Troleandomycin \\
\hline Bromo-succinic acid & Vancomycin \\
\hline $\mathrm{N}$-acetylneuraminic acid & D-mannose \\
\hline ahydroxy butyric acid & D-Raffinose \\
\hline Stachyose & Rifamycin SV \\
\hline Formic acid & Minocycline \\
\hline L-rhamnose & Lincomycin \\
\hline Nalidixic acid & D-arabitol \\
\hline${ }^{\alpha} \mathrm{D}$-lactose & Niaproof 4 \\
\hline
\end{tabular}

Table 1 (continued)

\begin{tabular}{ll}
\hline Positive reactions & \\
\hline Aztreonam & D-salicin \\
PH 5 & \\
\hline
\end{tabular}

L-alanine, L-glutamic acid, L-serine, gelatin some carboxylic acid, acetic acid and acetoacetic acid. It may grow well at $\mathrm{pH} 6$ and can also tolerate $1-8 \%$ of $\mathrm{NaCl}$. However, some of carbohydrates and amino acids were poorly metabolized by XP-2. The strain showed sensitivity to vancomycin, rifamycin $\mathrm{SV}$, lincomycin, minocycline, Niaproof 4, tetrazolium violet, and troleandomycin. The metabolic profile of XP-2 based on high and low consumption of carbohydrates, amino acids, and other chemical derivatives were depicted in Table1. To maintain the vital activities for survival, E. oxidotolerans JCM12280 ${ }^{\mathrm{T}}$ consumes compounds such as D-fructose, D-maltose, and gelatin. Our isolated XP-2 also consumes D-fructose, D-maltose, and gelatin compounds. Metabolic characteristics of XP-2 slightly matched with E. oxidotolerans JCM12280 ${ }^{\mathrm{T}}$. On the basis of the above $16 \mathrm{~S}$ rRNA sequence blasting, phylogenetic analysis, and biochemical and physiological characteristics, we designated XP-2 as Exiguobacterium oxidotolerans XP-2.

\section{Discussion}

In this study, we identified a pathogenic bacterial strain $\mathrm{XP}-2$, isolated from the abnormal diseased mature sporophytes. XP-2 could cause green-rotten disease (not abnormal disease) in healthy juvenile sporophytes in laboratory conditions. Pathogenecity of XP-2 was tested by both re-infection assay and by Koch's postulate. Based on the sequence of 16S rRNA gene and physiological and chemical characterization of XP-2, we designated XP-2 as Exiguobacterium oxidotolerans XP-2. This bacterium was definitely an opportunistic pathogenic bacterium for the cultivated S. japonica.

The genus Exiguobacterium was first designated by Collin in 1983. So far, 20 species have been identified within this genus from diverse habitats, including marine water, permafrost to hot spring, food processing plants, and soil (see review by Pandey 2020). Various species of Exiguobacterium have been studied for industrial use, including enzyme production (Kasana and Pandey 2018), bioremediation of pesticide, and degradation of toxic compounds (Rizvi et al. 2016; Mohapatra et al. 2017), and some of them have the potential to promote plant growth (Chauhan et al. 2015; Kumar and Verma 2018). The agroutility of Exiguobacterium has been confirmed by its ability 
to suppress the fungal diseases of cereal crops and to inhibit the growth and development of plant pathogens (Selvakumar et al. 2009).

Exiguobacterium spp. have been isolated from green, red, and brown seaweeds (Del olmo et al. 2018). Exiguobacterium marinum was isolated from the green seaweed Caulerpa cylindracea (Rizzo et al. 2016) and Exiguobacterium profundum from the brown seaweed Turbinaria ornata (Karthick and Mohanraju 2018). Moreover, Singh et al. (2011) reported that Exiguobacterium homiense associated with the red seaweed Gracilaria dura had the ability to produce growth promoting hormone enhancing the number of buds and growth of $G$. dura. Till date, no pathogenic Exiguobacterium species has been documented in seaweeds. However, Anguiano-Beltrán et al. (2012) reported that Exiguobacterium sp. could cause mortality on abalone in commercial farms at the post larval stage.

Exiguobacterium oxidotolerans was first reported in 2004 (Yumoto et al. 2004). A number of E. oxidotolerans T-2-2 ${ }^{\mathrm{T}}$ strains, like STR36, AMBL-20 T, SGAA-2, A011, N4-1p, CNU020, Kopri 20,246, and isolate 2, have been isolated from variety of the habitats like rhizosphere, glaciers, corals, sea mud and sediments, dead brown algae, and shrimps. These strains played a major role in enzyme production, such as exopolysaccharide and alkaline lipase production, and showed antimicrobial activity and Bgl1C ( $\beta$-glucosidase), catalase, and protease activity, and were useful for industrial applications (Lee et al. 2005; 2009; Chen et al. 2010; Bharti et al. 2013; Cai et al. 2014; Chellaram et al. 2015; Seki et al. 2017; Yasin et al. 2021).

So far, culture-dependent method and 16S rRNA gene amplicon sequencing have been applied for identifying the pathogenic bacteria of diseased cultivated S. japonica. By using conventional culture-dependent method, species of Pseudoalteromonas (Sawabe et al. 1998; 2000; Wang et al. 2008), Alteromonas (Wang et al. 2004, 2005; Peng and Li 2013), and Vibrio sp. (Wang et al. 2008) have been identified as the pathogenic bacteria for various diseased S. japonica. However, using 16S rRNA gene amplicon sequencing, Granulosicoccus, Litorimonas, Tenacibaculum, and Blastopirellula were found to be dominant in green rotten-diseased $S$. japonica sporelings as compared to the healthy ones at nursery stage (Li et al. 2020). It was implied that these genera were possibly associated with greenrotten disease of the sporelings of $S$. japonica. In the case of field cultivation during the harvest season (from April to June), Halomonas sp. was the most dominant bacterial species on green rotten-diseased sporophytes. OTUs of genera Sulfitobacter and Loktanella of the Roseobacter group were enriched in diseased tissues suggesting these taxa could be related to the opportunistic pathogens (Zhang et al. 2020). Different findings may have resulted from the limitation of the culture-dependent method and also the fact that different disease symptoms may be caused by different pathogenic bacteria. Moreover, the results from culturedependent method and using 16S rRNA gene amplicon sequencing could not be compared with each other, as these results focused on different diseases. Therefore, in order to gain deeper and comprehensive understanding of the pathogenic bacteria of the diseased cultivated S. japonica, it is highly recommended to combine the conventional culture-dependent method and 16S rRNA gene highthroughput sequencing. Additionally, whether the potential pathogenic bacteria identified by the 16S rRNA gene highthroughput sequencing are the actual pathogenic bacteria or not still need to be tested by isolation, purification, and re-infection assay. The findings of the pathogenic bacterium E. oxidotolerans XP-2 in this study enriched the list of the pathogenic bacteria for cultivated $S$. japonica.

So far, research on the diseases of commercially cultivated $S$. japonica is still at its early stages. The main issue for bacterial diseases of cultivated S. japonica is the complexity of disease outbreaks. Rather than re-occurring year after year, the observed disease outbreaks are highly variable with different disease symptoms in different years at both nursery stage and cultivation stage, which may be caused by fluctuations of biotic and abiotic parameters during cultivation in S. japonica farms (Prof. Gaoge Wang, pers. communication). Abnormal disease was found on the mature sporophytes in July 2018. Although we have tried to isolate and identify the pathogenic bacteria for abnormal disease, we have not been fully successful yet. The reasons for difficultly in identifying the pathogenic bacteria for commercially cultivated $S$. japonica can be summarized as follows: (1) it has been identified that pathogenic bacteria of the cultivated $S$. japonica are opportunistic pathogenic bacteria, which means that they are present on the healthy $S$. japonica and only become pathogenic when the environmental factors deteriorate during cultivation, for example, increased temperatures and the variation of light intensity. (2) Only about $1 \%$ of the epiphytic bacteria of S. japonica are cultivable, the true pathogenic bacteria maybe not cultivable using the conventional culture-dependent method. (3) Polymicrobial pathogenic bacteria have been found for coral diseases (Sato et al. 2016) and the red alga Delisea pulchra (Kumar et al. 2016). Polymicrobial pathogenic microorganisms also occurred in the sporelings of S. japonica at nursery stage. When re-infecting the healthy sporelings by combining one isolated pathogenic bacterial strain and two other fungal isolated pathogenic strains, disease symptoms appeared 3-4 h earlier compared to 8-12 $\mathrm{h}$ when re-infected by each individual pathogenic strain (Prof. Gaoge Wang pers. communication). (4) It is hard to identify which is the first causative agent whenever there is a disease outbreak because of the polymicrobial pathogenic agents. Therefore, E. oxidotolerans XP-2 is also an opportunistic pathogenic bacterium for the cultivated $S$. japonica. 


\section{Conclusions}

China is a world leader in the production of the brown seaweed $S$. japonica. With the successful cultivation of the $S$. japonica cultivation since the 1950s, numerous diseases of biotic and abiotic origin have been described at both nursery stage and field cultivation stage. Previous research were highly focused on observations and descriptions of the disease outbreaks. However, all strategies for disease management of commercially cultivated seaweeds are based on the fundamental understanding of the pathogenic bacteria. So far, very little is known about the virulence mechanisms induced by pathogenic bacteria and the virulence factors in the cultivated $S$. japonica. Elucidating the virulence mechanisms and how these processes are regulated by the biotic and abiotic environment is of urgent importance. Only once this has been achieved, rapid diagnosis can be applied for the effective management of $S$. japonica diseases. The identified pathogenic bacterium E. oxidotolerans XP-2 in this study will help to establish a stable experimental model of pathogenic bacteria and $S$. japonica to elucidate the virulence mechanisms. Diseases of $S$. japonica could be prevented and mitigated by the deeper understanding of the virulence mechanisms of the pathogenic bacteria in the near future.

Funding This study was sponsored by the Marine S \& T Fund of Shandong Province for Pilot National Laboratory for Marine Science and Technology (Qingdao) (2018SDKJ0406-5), the National Natural Science Foundation of China (41576158; 42076106), the Fundamental Research Funds for the Central Universities (201822025), National Key R\&D Program of China (2018YFD0900305), and Rongcheng Marine Industrial Technology Research Institute, Ludong University (KF20180002).

\section{References}

Anguiano-Beltrán C, Searcy-Bernal R, García-Ortega AM, García-Esquivel Z, Valenzuela-Espinoza E (2012) Effect of three bacterial isolates from a commercial hatchery on early red abalone (Haliotis rufescens) postlarvae. Aquac Int 20:993-1001

Bharti N, Yadav D, Barnawal D, Maji D, Kalra A (2013) Exiguobacterium oxidotolerans, a halotolerant plant growth promoting rhizobacteria, improves yield and content of secondary metabolites in Bacopa monnieri (L.) Pennell under primary and secondary salt stress. World J Microbiol Biotechnol 29:379-387

Cai Q, Zhang B, Chen B, Zhu Z, Lin W, Cao T (2014) Screening of biosurfactant producers from petroleum hydrocarbon contaminated sources in cold marine environments. Mar Pollut Bull 86:402-410

Chauhan H, Bagyaraj DJ, Selvakumar G, Sundaram SP (2015) Novel plant growth promoting rhizobacteria-prospects and potential. Appl Soil Ecol 95:38-53

Chellaram C, Praveen MM, John AA (2015) Antimicrobial activity of an epibiotic Exiguobacterium strain SGAA-2 from Gorgonian coral, Subergorgia suberosa (Pallas, 1766). Indian J Mar Sci 44:750-755
Chen D, Lin G, Shen S (1979) Studies on alginic acid-decomposing bacteria, I. Action of alginic acid-decomposing bacteria and alginase on Laminaria japonica. Oceanol Limnol Sinica 10:329-333 (In Chinese with English abstract)

Chen D, Lin G, Shen S (1981) Studies on alginic acid-decomposing bacteria, II. Rot disease of Laminaria summer sporeling caused by alginic acid-decomposing bacteria. Oceanol Limnol Sinica 12:133-137 (In Chinese with English abstract)

Chen D, Liu X, Liu X, Wang Q (1986) Studies on alginic acid decomposing bacteria IV. Distribution of alginic acid decomposing bacteria in Laminaria farm and its ecological significance. Oceanol Limnol Sinica 17:137-143

Chen S, Hong Y, Shao Z, Liu Z (2010) A cold-active $\beta$-glucosidase (Bgl1C) from a sea bacteria Exiguobacterium oxidotolerans A011. World J Microbiol Biotechnol 26:1427-1435

Del Olmo A, Picon A, Nuñez M (2018) The microbiota of eight species of dehydrated edible seaweeds from North West Spain. Food Microbiol 70:224-231

Ding ML (1990) The influence of environmental factors on rot disease of Laminaria caused by alginic acid decomposing bacteria. Acta Oceanol Sinica 12:224-230

Egan S, Harder T, Burke C, Steinberg P, Kjelleberg S, Thomas T (2013) The seaweed holobiont: understanding seaweed-bacteria interactions. FEMS Microbiol Rev 37:462-476

Egan S, Fernandes ND, Kumar V, Gardiner M, Thomas T (2014) Bacterial pathogens, virulence mechanism and host defence in marine macroalgae. Environ Microbiol 16:925-938

FAO (2016) The state of world fisheries and aquaculture.\&nbsp;Contributing to food security and nutrition for all. Rome: FAO, pp 200

Felsenstein J (1985) Confidence limits on phylogenies: an approach using the bootstrap. Evolution 39:783-791

Fisher MM, Wilcox LW, Graham LE (1998) Molecular characterization of epiphytic bacterial communities on charophycean green algae. Appl Environ Microbiol 64:4384-4389

Gachon CM, Sime-Ngando T, Strittmatter M, Chambouvet A, Kim GH (2010) Algal diseases: spotlight on a black box. Trends Plant Sci 15:633-640

Karthick P, Mohanraju R (2018) Antimicrobial potential of epiphytic bacteria associated with seaweeds of Little Andaman. India Front Microbiol 9:611

Kasana RC, Pandey CB (2018) Exiguobacterium: an overview of a versatile genus with potential in industry and agriculture. Crit Rev Biotechnol 38:141-156

Kim GH, Klochkova TA, Im SH (2016) Chloroplast virus causes greenspot disease in cultivated Pyropia of Korea. Algal Res 17:293-299

Kumar A, Verma JP (2018) Does plant-microbe interaction confer stress tolerance in plants: a review. Microbiol Res 207:41-52

Kumar V, Zozaya-Valdes E, Kjelleberg S, Thomas T, Egan S (2016) Multiple opportunistic pathogens can cause a bleaching disease in the red seaweed Delisea pulchra. Environ Microbiol 18:3962-3975

Kumar S, Stecher G, Li M, Knyaz C, Tamura K (2018) MEGA X: molecular evolutionary genetics analysis across computing platforms. Mol Biol Evol 35:1547-1549

Lee YK, Sung KC, Yim JH, Park KJ, Chung HS, Lee HK (2005) Isolation of protease-producing Arctic marine bacteria. Ocean Polar Res 27:215-219

Lee DH, Oh KH, Kahng HY (2009) Molecular analysis of antioxidant genes in the extremohalophile marine bacterium Exiguobacterium sp. CNU020. Biotechnol Lett 31:1245-1251

Li J, Pang S, Shan T, Su L (2020) Changes of microbial community structures associated with seedlings of Saccharina japonica at early stage of outbreak of green rotten disease. J Appl Phycol 32:1323-1327

Lin W, Zhang WW, Yan XJ, Duan DL (2004) Distribution and reinfection of alginic acid decomposing bacteria on juvenile Laminaria 
japonica. Oceanol Limnol Sinica 35:562-567 (In Chinese with English abstract)

Liu CS, Wang LL, Wang M, Tang XX (2002) Difference analysis of infection activity of alginic acid decomposing bacteria infecting Laminaria japonica. Mar Sci 26:44-47 (In Chinese with English abstract)

Maurin N, Gourret JP, Tivoli B (1993) Histopathology of the interaction between Ascochyta fabae and Vicia faba: comparison of susceptible and resistant reactions. Agronomie 13:921-927

Mohapatra RK, Parhi PK, Thatoi H, Panda CR (2017) Bioreduction of hexavalent chromium by Exiguobacterium indicum strain MW1 isolated from marine water of Paradip Port, Odisha. India Chem Ecol 33:114-130

Moreno C, Romero J, Espejo RT (2002) Polymorphism in repeated 16S rRNA genes is a common property of type strains and environmental isolates of the genus Vibrio. Microbiology 148:1233-1239

Oppenheimer CH, ZoBell CE (1952) The growth and viability of sixtythree species of marine bacteria as influenced by hydrostatic pressure. J Mar Res 11:10-18

Pandey N (2020) Exiguobacterium. In: Amaresan N, Kumar MS, Annapurna K, Kumar K, Sankaranarayanan A (eds) Beneficial Microbes in Agro-Ecology. London: Academic Press, pp 169-183

Peng Y, Li WA (2013) Bacterial pathogen infecting gametophytes of Saccharina japonica (Laminariales, Phaeophyceae). Chin J Oceanol Limn 31:366-373

Rizvi FZ, Kanwal W, Faisal M (2016) Chromate-reducing profile of bacterial strains isolated from industrial effluents. Pol J Environ Stud 25:2121-2128

Rizzo L, Fraschetti S, Alifano P, Pizzolante G, Stabili L (2016) The alien species Caulerpa cylindracea and its associated bacteria in the Mediterranean Sea. Mar Biol 163:4

Sato Y, Civiello M, Bell SC, Willis BL, Bourne DG (2016) Integrated approach to understanding the onset and pathogenesis of black band disease in corals. Environ Microbiol 18:752-765

Sawabe T, Ezura Y, Kimura T (1992) Characterization of an alginolytic marine bacterium from decaying Rishiri kombu Laminaria japonica var. ochotensis. Nippon Suisan Gakkaishi 58:141-145

Sawabe T, Makino H, Tatsumi M, Nakano K, Tajima K, Iqbal MM, Yumoto I, Ezura Y, Christen R (1998) Pseudoalteromonas bacteriolytica sp. nov., a marine bacterium that is the causative agent of red spot disease of Laminaria japonica. Int J Syst Bacteriol 48:769-774

Sawabe T, Tanaka R, Iqbal MM, Tajima K, Ezura Y, Ivanova EP, Christen R (2000) Assignment of Alteromonas elyakovii KMM $162 \mathrm{~T}$ and five strains isolated from spot-wounded fronds of Laminaria japonica to Pseudoalteromonas elyakovii comb. nov. and the extended description of the species. Int J Syst Evol Microbiol 50:265-271

Seki H, Nakazato K, Hamada-Sato N (2017) Adenosine monophosphate degradation and inosinic acid accumulation in the shrimp Penaeus japonicus. Int Aquat Res 9:37-52

Selvakumar G, Joshi P, Nazim S, Mishra PK, Kundu S, Gupta HS (2009) Exiguobacterium acetylicum strain 1P (MTCC 8707) a novel bacterial antagonist from the North Western Indian Himalayas. W J Microbiol Biotechnol 25:131-137

Singh RP (2013) Studies on certain seaweed-bacterial interaction from Saurashtra coast. Dissertation, Maharaja Krishnakumarsinhji Bhavnagar University

Singh RP, Reddy CRK (2014) Seaweed-microbial interactions: key functions of seaweed-associated bacteria. FEMS Microbiol Ecol $88: 213-230$

Singh RP, Bijo AJ, Baghel RS, Reddy CRK, Jha B (2011) Role of bacterial isolates in enhancing the bud induction in the industrially important red alga Gracilaria dura. FEMS Microbiol Ecol 76:381-439
Singh NK, Raichand R, Kaur I, Kaur C, Pareek S, Mayilraj S (2013) Exiguobacterium himgiriensis sp. nov. a novel member of the genus Exiguobacterium, isolated from the Indian Himalayas. Antonie Van Leeuwenhoek 103:789-796

Tamura K, Nei M (1993) Estimation of the number of nucleotide substitutions in the control region of mitochondrial DNA in humans and chimpanzees. Mol Biol Evol 10:512-526

Thompson JD, Gibson TJ, Plewniak F, Jeanmougin F, Higgins DG (1997) The CLUSTAL_X windows interface: flexible strategies for multiple sequence alignment aided by quality analysis tools. Nucleic Acid Res 25:4876-4882

Tseng C (1994) Anthology of Tseng Cheng-Kui. Beijing: Ocean Press, pp 871-873

Vairappan CS, Suzuki M, Motomura T, Ichimura T (2001) Pathogenic bacteria associated with lesions and thallus bleaching symptoms in the Japanese kelp Laminaria religiosa Miyabe (Laminariales, Phaeophyceae). Hydrobiologia 445:183-191

Wang YL, Tang XX, Yang Z (2003a) The selection and growth conditions of alginic acid decomposing bacteria. J Fish Sci China 10:51-54 (In Chinese with English abstract)

Wang LL, Tang XX, Wang M, Zhang PY (2003b) The roles played by alginic acid decomposing bacteria during the time of green decay disease of Laminaria japonica. J Ocean Univ China 33:245-248 (In Chinese with English abstract)

Wang G, Lin W, Zhang L, Yan X, Duan D (2004) Programmed cell death in Laminaria japonica (Phaeophyta) tissues infected with alginic acid decomposing bacterium. Pro Nat Sci 14:1064-1068

Wang G, Wei L, Xiaojun Y, Delin D (2005) Study on the enzymatic activity of Caspase-3 in response to alginic acid decomposing bacteria in Laminaria japonica Aresch. (Phaeophyta). High Technol Lett (english Edition) 11:80-84

Wang Y, Tang XX, Yang Z, Yu ZM (2006) Effect of alginic acid decomposing bacterium on the growth of Laminaria japonica (Phaeophyceae). J Environ Sci 18:543-551

Wang G, Shuai L, Li Y, Lin W, Zhao X, Duan D (2008) Phylogenetic analysis of epiphytic marine bacteria on hole-rotten diseased sporophytes of Laminaria japonica. J Appl Phycol 20:403-409

Wang G, Lu B, Shuai L, Li D, Zhang R (2014) Microbial diseases of nursery and field-cultivated Saccharina japonica (Phaeophyta) in China. Algol Stud 145/146:39-51

Yasin MT, Ali Y, Ahmad K, Ghani A, Amanat K, Basheir MM, Faheem M, Hussain S, Ahmad B, Hussain A, Bokhari SAI (2021) Alkaline lipase production by novel meso-tolerant psychrophilic Exiguobacterium sp. strain (AMBL-20) isolated from glacier of northeastern Pakistan. Arch Microbiol 203:1309-1320

Ying JJ, Zhang SL, Huang CY, Xu L, Zhao Z, Wu M, Sun C (2019) Algicoccus marinus gen. nov. sp. nov., a marine bacterium isolated from the surface of brown seaweed Laminaria japonica. Arch Microbiol 201:943-950

Yumoto I, Nakamura A, Iwata H, Kojima K, Kusumoto K, Nodasaka Y, Matsuyama H (2002) Dietzia psychralcaliphila sp. nov., a novel, facultatively psychrophilic alkaliphile that grows on hydrocarbons. Int J Syst Evol Microbiol 52:85-90

Yumoto I, Hishinuma-Narisawa M, Hirota K, Shingyo T, Takebe F, Nodasaka Y, Matsuyama H, Hara I (2004) Exiguobacterium oxidotolerans sp. nov., a novel alkaliphile exhibiting high catalase activity. Int J Syst Evol Microbiol 54:2013-2017

Zhang R, Chang L, Xiao L, Zhang X, Han Q, Li N, Egan S, Wang G (2020) Diversity of the epiphytic bacterial communities associated with commercially cultivated healthy and diseased Saccharina japonica during the harvest season. J Appl Phycol 32:2071-2080

Publisher's Note Springer Nature remains neutral with regard to jurisdictional claims in published maps and institutional affiliations. 